\title{
Effect of the Phosphorus Gettering on Si Heterojunction Solar Cells
}

\author{
Hyomin Park,, ${ }^{1}$ Sung Ju Tark, ${ }^{1}$ Chan Seok Kim, ${ }^{1}$ Sungeun Park, ${ }^{1}$ Young Do Kim, ${ }^{1}$ \\ Chang-Sik Son, ${ }^{2}$ Jeong Chul Lee, ${ }^{3}$ and Donghwan Kim ${ }^{1}$ \\ ${ }^{1}$ Department of Materials Science and Engineering, Korea University, Anam-Dong, Seongbuk-gu, Seoul 136-713, Republic of Korea \\ ${ }^{2}$ Department of Electronic Materials Engineering, Silla University, San1-1, Guebup-Dong, Sasang-gu, \\ Busan 617-736, Republic of Korea \\ ${ }^{3}$ KIER-UNIST Advanced Center for Energy, Korea Institute of Energy Research, UNIST-gil 50, Eonyang-eup, Ulju-gun, \\ Ulsan 689-798, Republic of Korea
}

Correspondence should be addressed to Donghwan Kim, donghwan@korea.ac.kr

Received 9 November 2011; Accepted 17 December 2011

Academic Editor: Junsin Yi

Copyright (c) 2012 Hyomin Park et al. This is an open access article distributed under the Creative Commons Attribution License, which permits unrestricted use, distribution, and reproduction in any medium, provided the original work is properly cited.

To improve the efficiency of crystalline silicon solar cells, should be collected the excess carrier as much as possible. Therefore, minimizing the recombination both at the bulk and surface regions is important. Impurities make recombination sites and they are the major reason for recombination. Phosphorus $(\mathrm{P})$ gettering was introduced to reduce metal impurities in the bulk region of Si wafers and then to improve the efficiency of Si heterojunction solar cells fabricated on the wafers. Resistivity of wafers was measured by a four-point probe method. Fill factor of solar cells was measured by a solar simulator. Saturation current and ideality factor were calculated from a dark current density-voltage graph. External quantum efficiency was analyzed to assess the effect of $\mathrm{P}$ gettering on the performance of solar cells. Minority bulk lifetime measured by microwave photoconductance decay increases from 368.3 to $660.8 \mu \mathrm{s}$. Open-circuit voltage and short-circuit current density increase from 577 to $598 \mathrm{mV}$ and 27.8 to $29.8 \mathrm{~mA} / \mathrm{cm}^{2}$, respectively. The efficiency of solar cells increases from 11.9 to $13.4 \%$. P gettering will be feasible to improve the efficiency of Si heterojunction solar cells fabricated on P-doped Si wafers.

\section{Introduction}

Solar cells have attracted great attention as a promising alternative energy source and various ways have been investigated to improve their performances. To obtain high-efficiency solar cells, minority carriers should have a long lifetime and a low recombination velocity [1]. Currently, single-, multicrystalline or amorphous silicon-based solar cells show high efficiency because of their reliability, scalability, and performance. However, metal impurities incorporated in Si wafers, such as $\mathrm{Fe}, \mathrm{Ni}$, and $\mathrm{Cu}$, are highly mobile, diffuse over long distances, and act as a recombination center [2-4]. Furthermore, solar cell performance is largely limited by the regions of poorest material quality [4]. Such recombination center in the wafers deteriorates carrier collection efficiency. Therefore, impurity gettering has been widely studied to reduce their deleterious effect. Several methods have been investigated, including spontaneously occurring and intentionally formed sinks for the transition metals - at the surface and bulk. Depending on where we capture metal impurities, it is classified to intrinsic and extrinsic gettering. Intrinsic gettering is involving the metal impurity trapping sites mainly in the bulk region. External gettering is that generating stress silicon lattice which acts as a sink by external means such as abrasion grooving or phosphorus diffusion. Extrinsic impurity gettering in Si wafers is appropriate since solar cells employ the whole bulk region which is used as generation points. Furthermore, generated carriers move through the bulk region to electrodes, less recombination sites in bulk goes to better efficiency of solar 
cells. Among extrinsic gettering, phosphorus (P) gettering is widely studied because it can be easily prepared by the diffusion of P [5-9].

Si heterojunction solar cells are one of important high efficiency solar cells showing a high open-circuit voltage and a low absorption in the emitter region.

Amorphous Si thin film has a large energy bandgap; Si heterojunction solar cells show a high open-circuit voltage and a low absorption in the emitter region. Since most light is absorbed in the bulk region of heterojunction silicon solar cells, it is important to have less recombination sites at the bulk region which reduce the diffusion length of excess carriers and collection efficiency.

In this work, we introduced extrinsic $\mathrm{P}$ gettering into the fabrication process of Si heterojunction solar cells and investigated the effect of $\mathrm{P}$ gettering on the performance of solar cells.

\section{Experimental}

Low-quality n-type monocrystalline $\mathrm{Si}$ wafers with the thickness of $170 \mu \mathrm{m}$ were doped by P into (100) plane and showed the resistivity of $3-5 \Omega \mathrm{cm}$. They underwent saw damage etching (SDE). Then, an aqueous hydrochloric acid and peroxide mixture (HPM) were used to remove metal particles from their surfaces. After finishing each process, the Si wafers were rinsed with DI water. We skipped texturing process to eliminate unwanted process variables.

$\mathrm{P}$ gettering has been reported to occur at an optimum temperature as it relies on the transportation of released impurities towards a segregation region near the surface of the samples [10]. Hence, the temperature and duration of $\mathrm{P}$ diffusion were expected to affect the gettering efficiency. Therefore, Si wafers were gettered at 750, 800, 850 , and $900^{\circ} \mathrm{C}$ for 30 minutes in a quartz tube furnace, while a reference sample was not gettered. The resistivity of P-gettered Si wafer was measured at 9 points. Phosphosilicate glass (PSG) layers were removed in buffered oxide etch (BOE) solution. To remove the gettered layers where impurities were assumed to be gathered, samples were immersed in potassium hydroxide $(\mathrm{KOH})$ solution for 5 minutes to etch back. The reference underwent the same etch-back process. Bulk lifetime was measured by iodine passivation using microwave photoconductance decay $(\mu \mathrm{w}-\mathrm{PCD})$.

Si heterojunction solar cells of $1 \times 1 \mathrm{~cm}^{2}$ were fabricated after finishing $\mathrm{P}$ gettering. $10 \mathrm{~nm}$ intrinsic a-Si:H films were deposited by hot wire chemical vapor deposition (HWCVD) using silane $\left(\mathrm{SiH}_{4}\right)$ and $\mathrm{H}_{2}$ as precursor gases. $10 \mathrm{~nm} \mathrm{P-}$ doped and $20 \mathrm{~nm}$ n-doped a-Si:H films were then formed by plasma enhanced CVD (PECVD) using $\mathrm{SiH}_{4}, \mathrm{H}_{2}$, and diborane $\left(\mathrm{B}_{2} \mathrm{H}_{6}\right)$ or phosphine $\left(\mathrm{PH}_{3}\right)$. After deposition of intrinsic a-Si:H films, front and back electrodes were formed by evaporation. Finally, edge isolation process was carried out in a 4:1 ( $\mathrm{HCl}: \mathrm{DI}$ water) mixed solution. Processing sequence is described in Figure 1. Generally, it is hard to detect metal impurities concentration in crystalline silicon wafer because of the detection limit. Therefore, we analyzed wafer characteristics and cell characteristics to deduce the $\mathrm{P}$ gettering effect. The saturation current and ideality factor of Si heterojunction solar cells were calculated from their dark currents and voltages. Short-circuit current density, open circuit voltage, and fill factor of the solar cells were measured using a solar simulator. External quantum efficiency was analyzed between 400 to $1100 \mathrm{~nm}$ wavelength to assess the electron-hole separation and collection at the bulk region.

\section{Results and Discussion}

The resistivity of $\mathrm{Si}$ wafers is $3-5 \Omega \mathrm{cm}$ before $\mathrm{P}$ gettering. The sheet resistances of P-gettered samples as a function of gettering temperature are shown in Figure 2. Resistivity of gettered sample abruptly decreases at $800^{\circ} \mathrm{C}$ from 2.7 to $0.9 \Omega \mathrm{cm}$. With the increasing gettering temperature, the resistivity decreases since the rate of $\mathrm{P}$ incorporation into substitutional sites of $\mathrm{Si}$ is enhanced by increased thermal activation at higher gettering temperature.

The minority carrier lifetime and diffusion length as a function of gettering temperature are shown in Figure 3. The bulk lifetime of the nongettered reference sample is $368.3 \mu \mathrm{s}$. Those of the gettered samples at $750,800,850$, and $900^{\circ} \mathrm{C}$ are $615.4,660.8,343.0$, and $301.4 \mu$ s, respectively. While the bulk lifetime shows the longest value at $800^{\circ} \mathrm{C}$, which is $292.5 \mu \mathrm{s}$ higher than that of the nongettered sample, the bulk lifetime shows the shortest value at $900^{\circ} \mathrm{C}$, which is $56.0 \mu \mathrm{s}$ shorter than that of the nongettered sample. Average diffusion length varies between 610.5 and $886.5 \mu \mathrm{m}$ depending on gettering temperature. The diffusion lengths of the gettered samples at 750 and $850^{\circ} \mathrm{C}$ are 835.9 and $634.6 \mu \mathrm{m}$, respectively. While the diffusion length shows the longest value at $800^{\circ} \mathrm{C}$, the diffusion length shows the shortest value at $900^{\circ} \mathrm{C}$.

Figure 4 shows the mapping of bulk lifetime and its probability distribution for (a) nongettered sample and gettered smaples at (b) 750 , (c) 800 , (d) 850 , and (e) $900^{\circ} \mathrm{C}$. The nongettered sample shows that over $90 \%$ of the substrate has a bulk lifetime below $407.4 \mu$ s and its $10 \%$ has a bulk lifetime below $195.0 \mu$ s. Its $80 \%$ has bulk lifetime between 195.0 and $407.4 \mu \mathrm{s}$, while $90 \%$ of the substrate for the sample gettered at $800^{\circ} \mathrm{C}$ shows a bulk lifetime over $501.2 \mu$ s. The mapping of bulk lifetime and its probability distribution of the samples gettered at 750 and $800^{\circ} \mathrm{C}$ are similar, though the sample gettered at 750 shows widely distributed values as compared with those of $800^{\circ} \mathrm{C}$.

The variation of lifetime and its probability distribution by gettering temperature can be explained by the diffusioninduced gettering of impurities as shown in Figure 5 [9]. When thermal activation energy is given in $\mathrm{Si}$ wafer, impurities are released from energetic binding and diffused through Si wafer. Then they are finally captured where the emitter acted as a sink. Here, experiment data shows that there is an optimized temperature of gettering. Metal impurities elimination efficiency of $\mathrm{P}$ gettering depends on the transport of impurities and solubility segregation. It was reported that there is competing effectiveness of two processes responsible for segregation gettering, that is, impurity transport and solubility segregation, the latter 


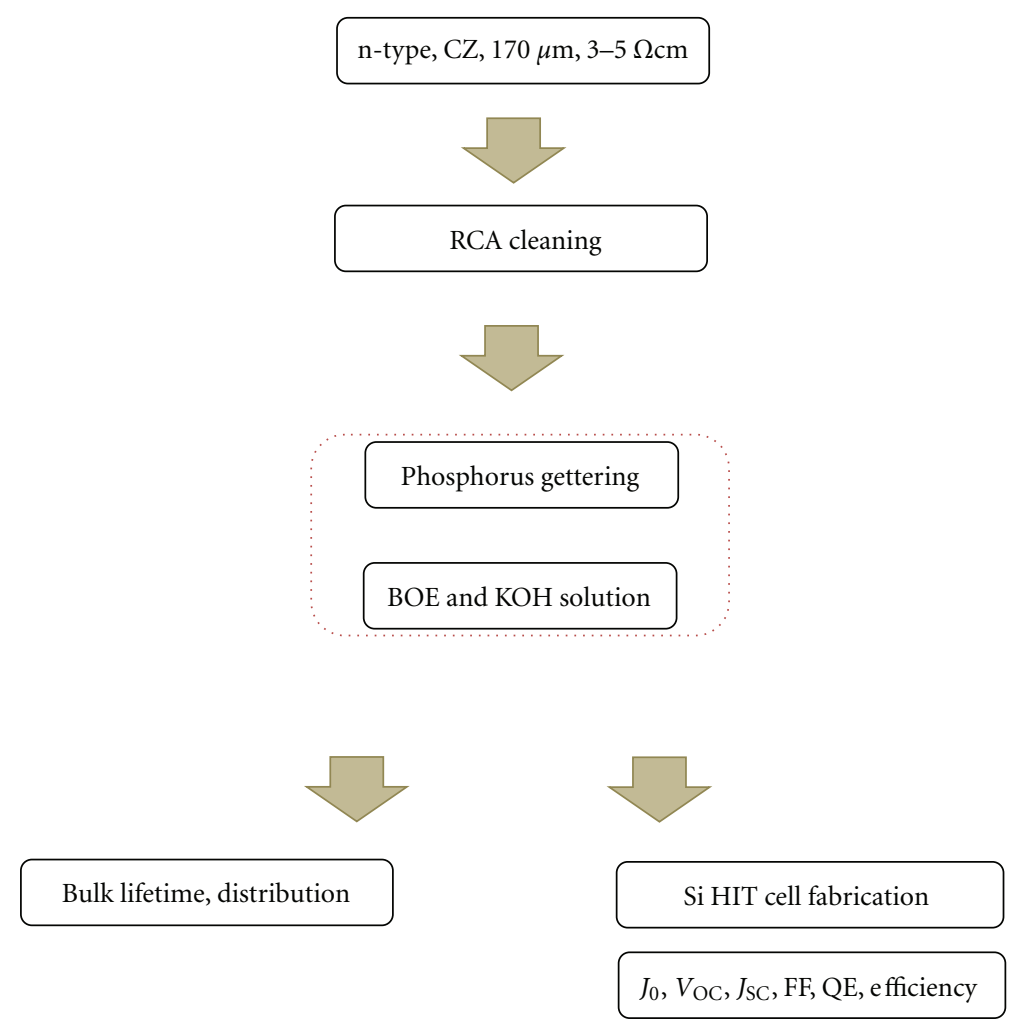

FIGURE 1: Processing sequence of samples for analysis.

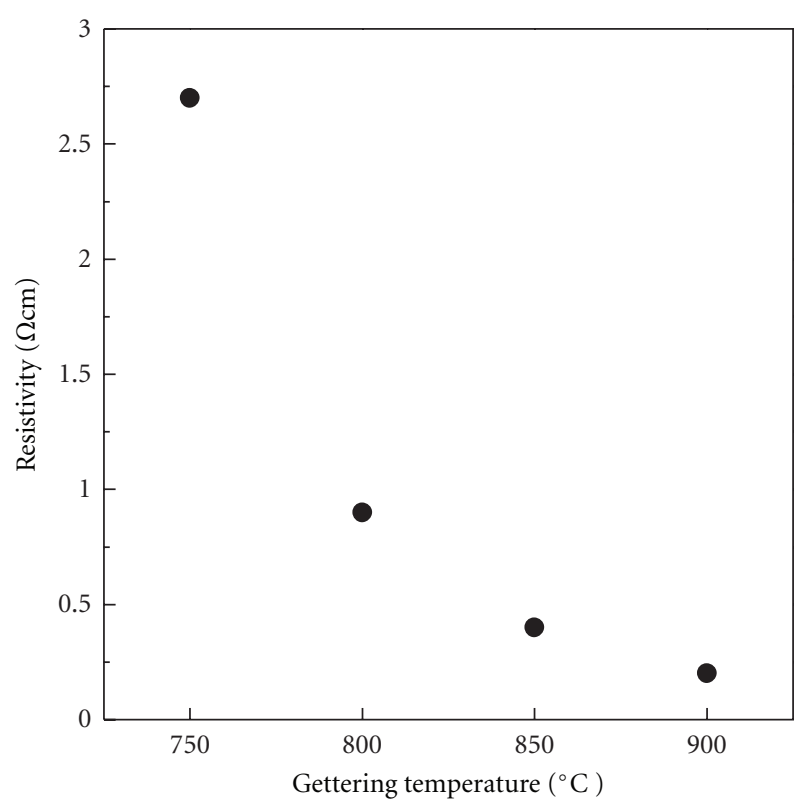

FIGURE 2: Resistivity as a function of gettering temperature.

process being characterized by a decreasing segregation coefficient with increasing temperature $[8,11]$. At high temperature, metal solubility is large, so required time for precipitation at the gettered region becomes long. However, if the gettering temperature is too high, crystallographic

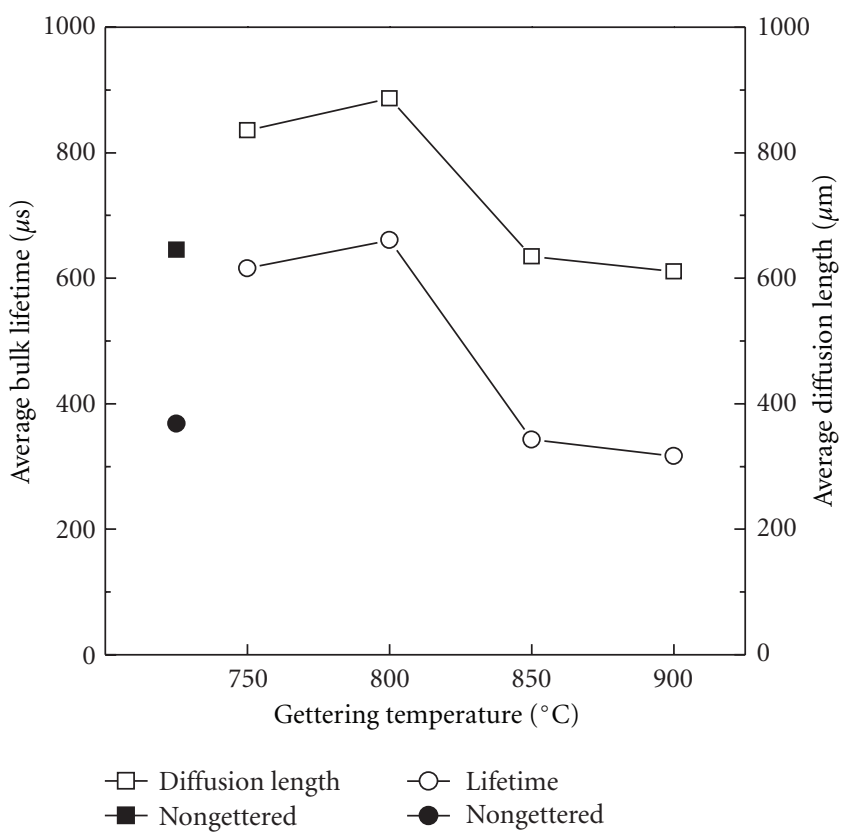

Figure 3: Bulk life time and bulk diffusion length as a function of gettering temperature.

defects are formed [12]. Gettering temperature should be decided after considering the diffusion, precipitate, and segregation of metal impurities. 


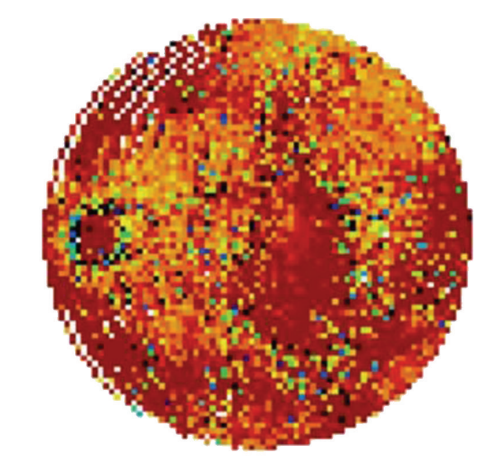

- 300

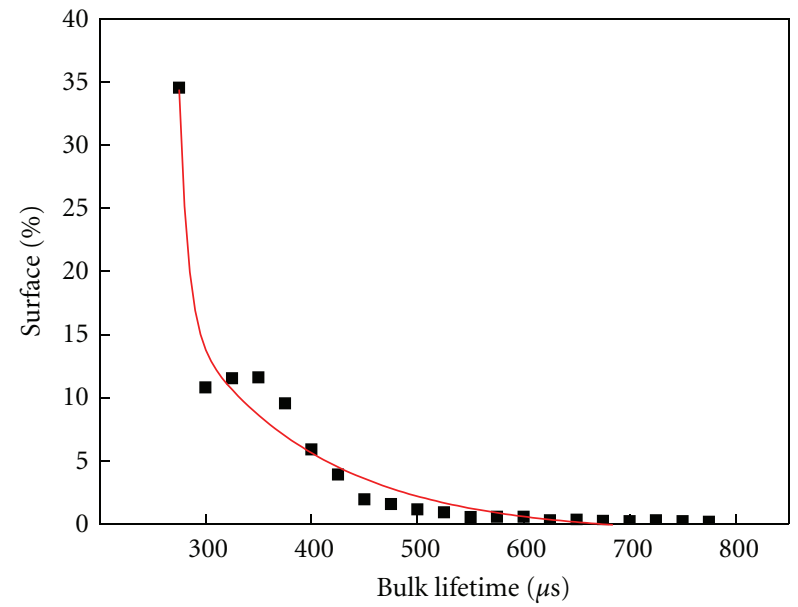

- Nongettered sample

(a)
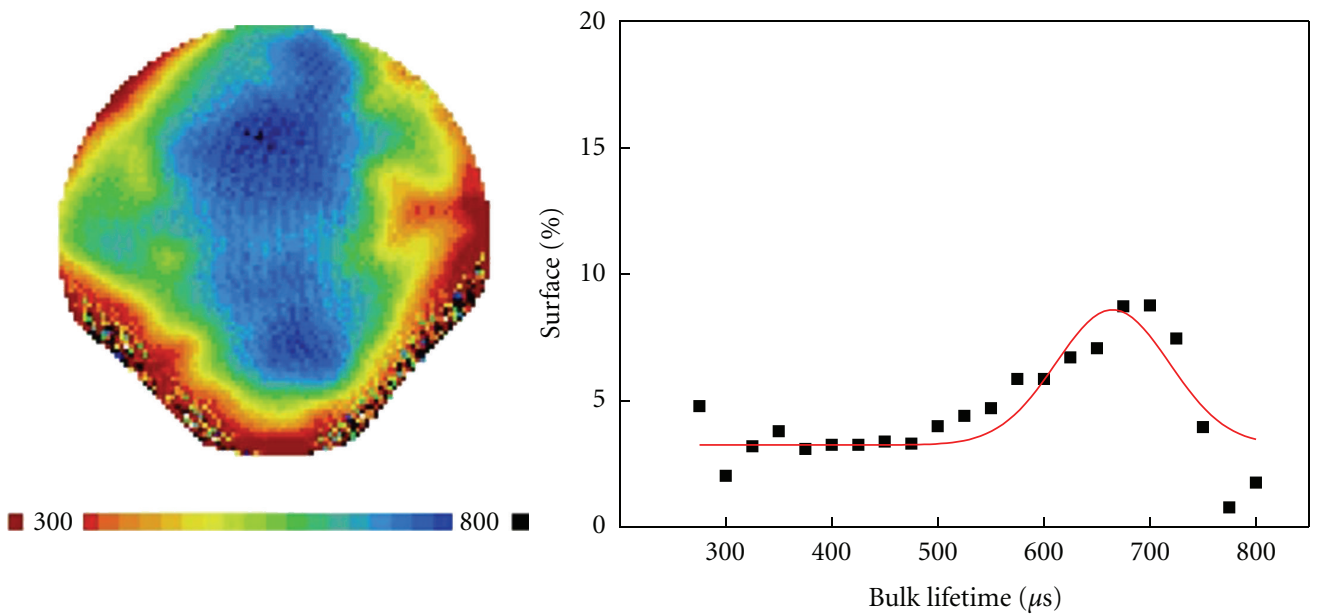

- 750 gettered sample

(b)
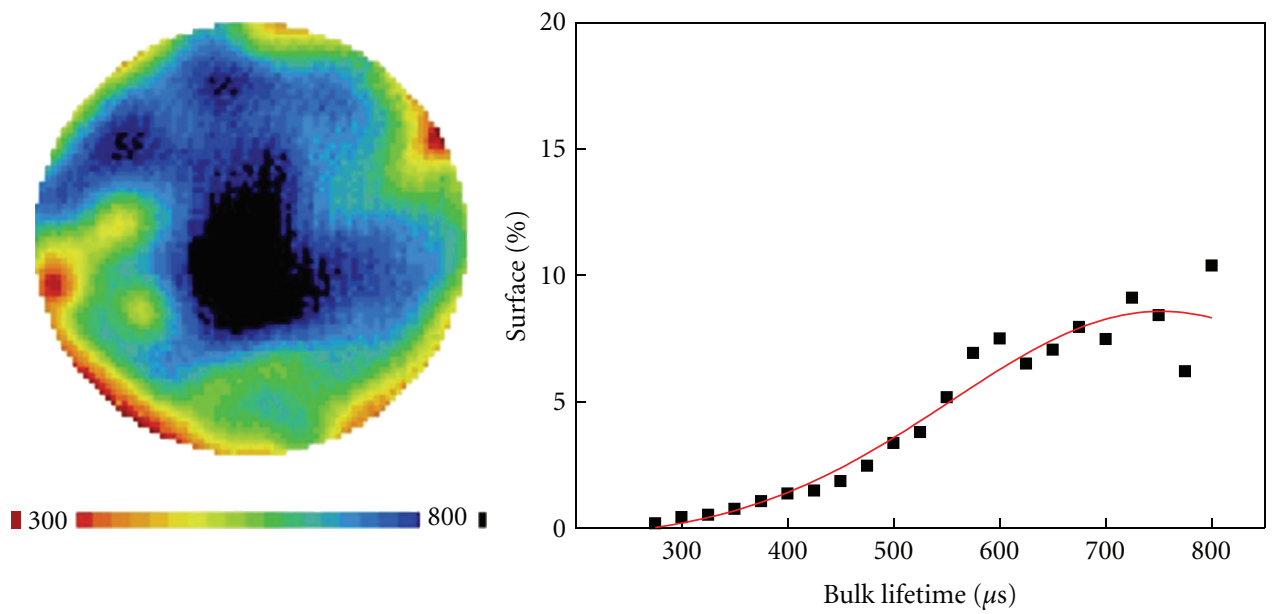

- 800 gettered sample

(c)

FIgURe 4: Continued. 

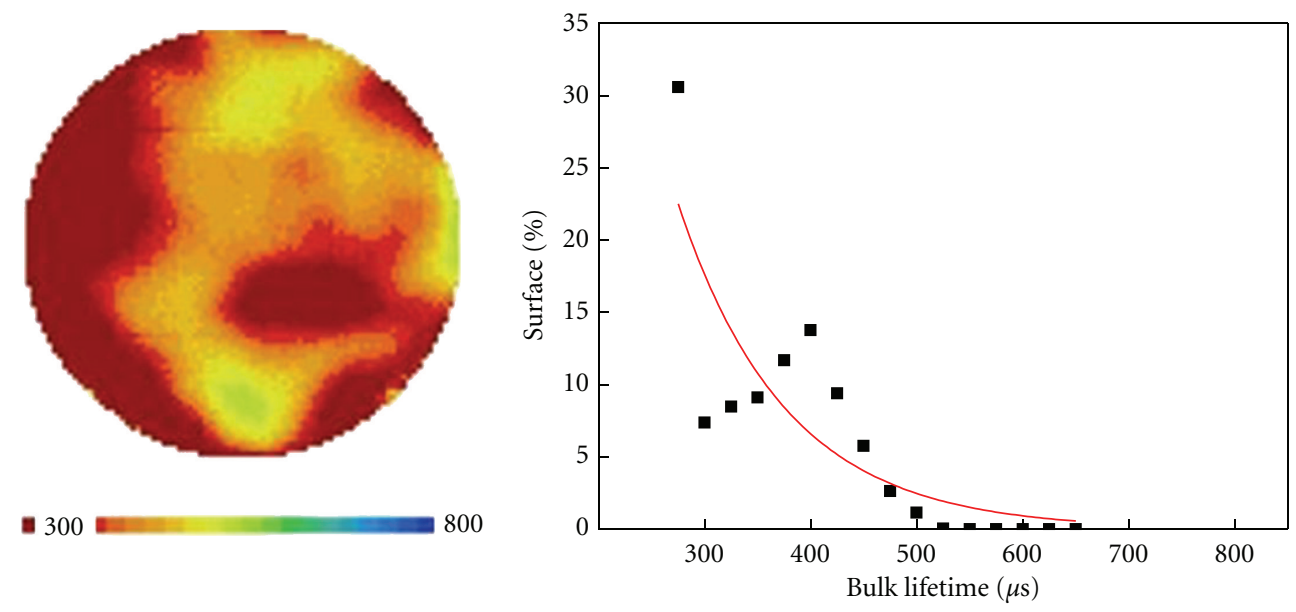

- 850 gettered sample

(d)
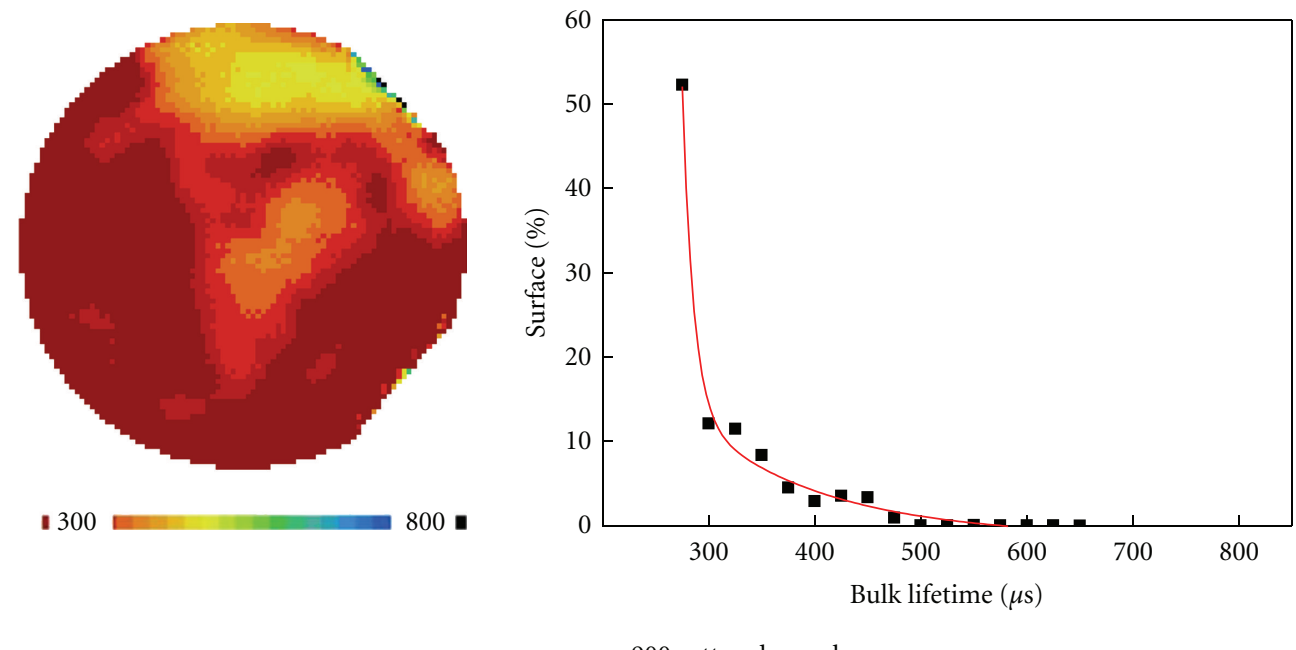

- 900 gettered sample

(e)

FIGURE 4: Mapping of bulk lifetime and its probability distribution for (a) nongettered sample and gettered samples at (b) 750, (c) 800, (d) 850 , and (e) $900^{\circ} \mathrm{C}$.

Figure 6 shows the illuminated current-voltage curves of nongettered and gettered samples. The sample gettered at $800^{\circ} \mathrm{C}$ shows the highest $V_{\mathrm{oc}}$ and $J_{\mathrm{sc}}$ values, $598 \mathrm{mV}$ and $29.8 \mathrm{~mA} / \mathrm{cm}^{2}$, respectively. The samples gettered at 850 and $900^{\circ} \mathrm{C}$ do not show better properties than those of nongettered sample. For all the samples, $V_{\mathrm{oc}}$ values are between 581 and $598 \mathrm{mV}$, and $J_{\mathrm{sc}}$ values are between 27.1 and $29.8 \mathrm{~mA} / \mathrm{cm}^{2}$. Fill factor is calculated from the currentvoltage curves. With the increasing gettering temperature, the fill factor slightly increases up to $800^{\circ} \mathrm{C}$ and then slightly increases up to $900^{\circ} \mathrm{C}$. The sample gettered at $800^{\circ} \mathrm{C}$ shows the highest value of $75.3 \%$.

$\mathrm{P}$ gettering was undertaken to suppress recombination due to impurities in the bulk region before the fabrication of Si heterojunction solar cells. As P gettering mainly affects the bulk or base region of the cells, we focus on variations in characteristics of quasineutral region than emitter region.
From the dark current-voltage curves, ideality factor and saturation current can be calculated. $J_{0}$ is obtained by extrapolation to $V=0$ [12]. Calculated saturation current and ideality factor as a function of gettering temperature are shown in Figure 7. The nongettered sample has a saturation current of $1.5 \times 10^{-8} \mathrm{~mA} / \mathrm{cm}^{2}$ in its quasi-neutral region. With the increasing gettering temperature, the saturation current decreases up to $800^{\circ} \mathrm{C}$ and then increase up to $900^{\circ} \mathrm{C}$. The sample gettered at $800^{\circ} \mathrm{C}$ shows the lowest value of $0.5 \times 10^{-8} \mathrm{~mA} / \mathrm{cm}^{2}$. Ideality factors were calculated from the relationship [13]

$$
n=\frac{q}{l_{n} m k T}=\frac{q}{2.3 m k T}
$$

In the quasi-neutral region, the ideality factor of nongettered sample is 1.65 . With the increasing gettering temperature, the ideality factor decreases up to $800^{\circ} \mathrm{C}$ and then increases up 


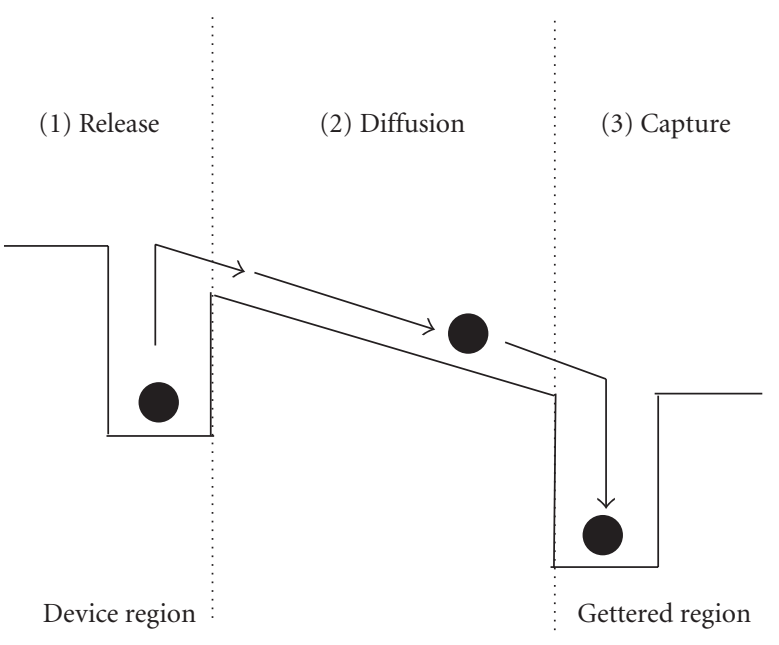

FIGURE 5: Sketch of the basic principle of diffusion-induced gettering of impurities.

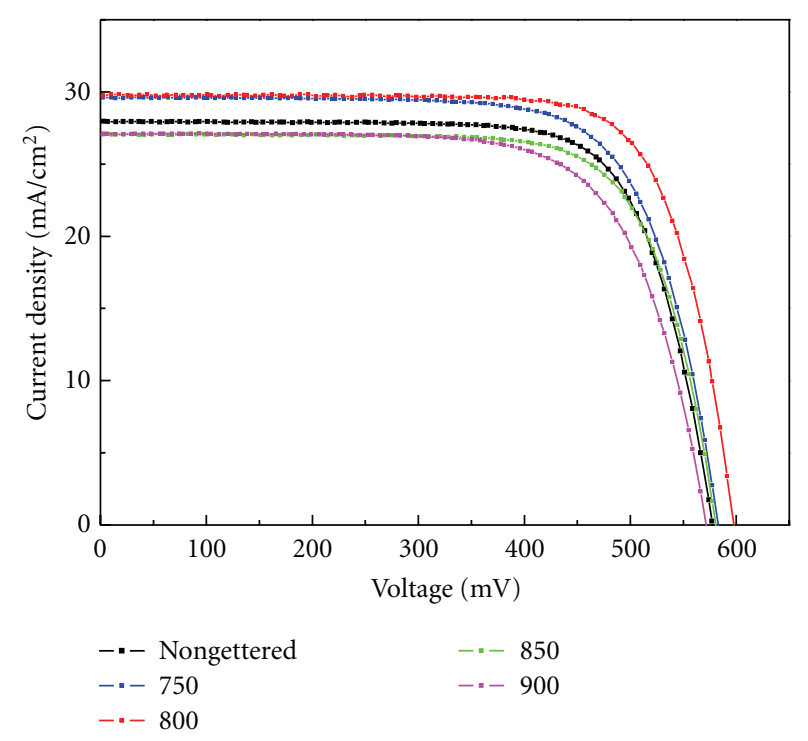

FIGURE 6: Illuminated current density-voltage curves of nongettered and gettered samples.

to $900^{\circ} \mathrm{C}$; this is the same tendency with the dependence of saturation current on the gettering temperature. The sample gettered at $800^{\circ} \mathrm{C}$ shows the lowest value of 1.56 .

External quantum efficiency (EQE) plots of the $\mathrm{Si}$ heterojunction solar cells are shown in Figure 8. We consider response to wavelength between 420 to $1100 \mathrm{~nm}$ corresponding to the signal from the bulk region. Responses of 750 and $800^{\circ} \mathrm{C}$ gettered samples show higher signal than that of the nongettered sample. The sample gettered at $800^{\circ} \mathrm{C}$ shows a superior response over all the wavelengths. However, samples gettered at $850^{\circ} \mathrm{C}$ and $900^{\circ} \mathrm{C}$ show a worse response than that of nongettered sample.

Ideality factors, $J_{0}, V_{\mathrm{oc}}, J_{\mathrm{sc}}$, fill factors, and efficiencies are summarized in Table 1 . The dependences of these parameters on the gettering temperature as described above explain that the sample gettered at $800^{\circ} \mathrm{C}$ show the best value, and then

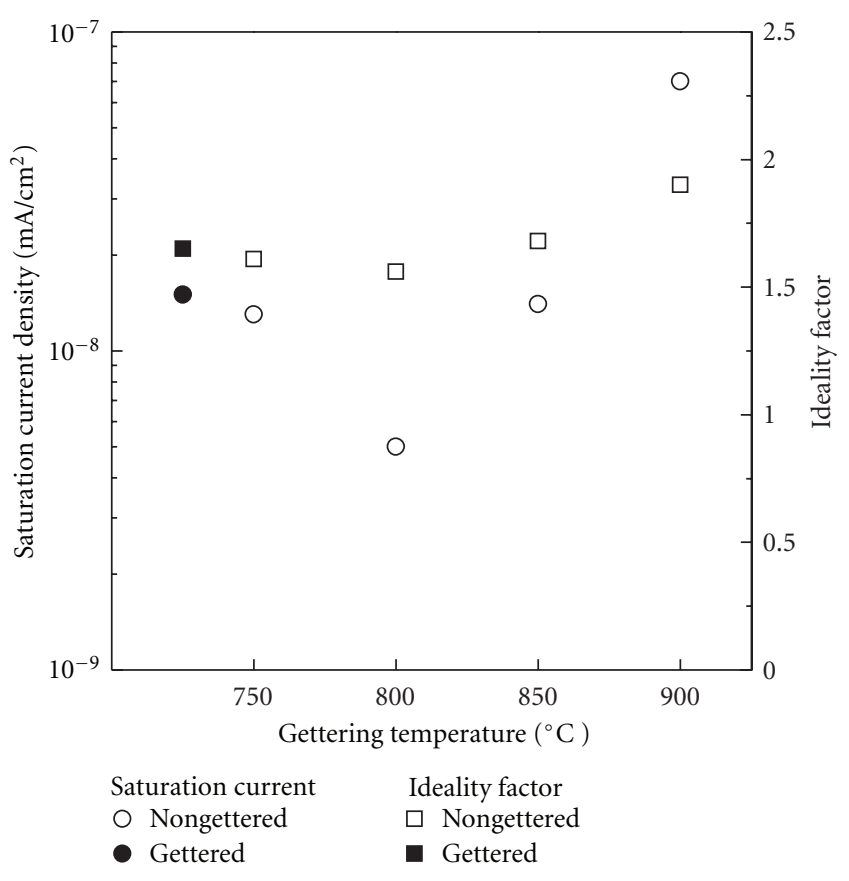

Figure 7: Calculated saturation current and ideality as a function of gettering temperature.

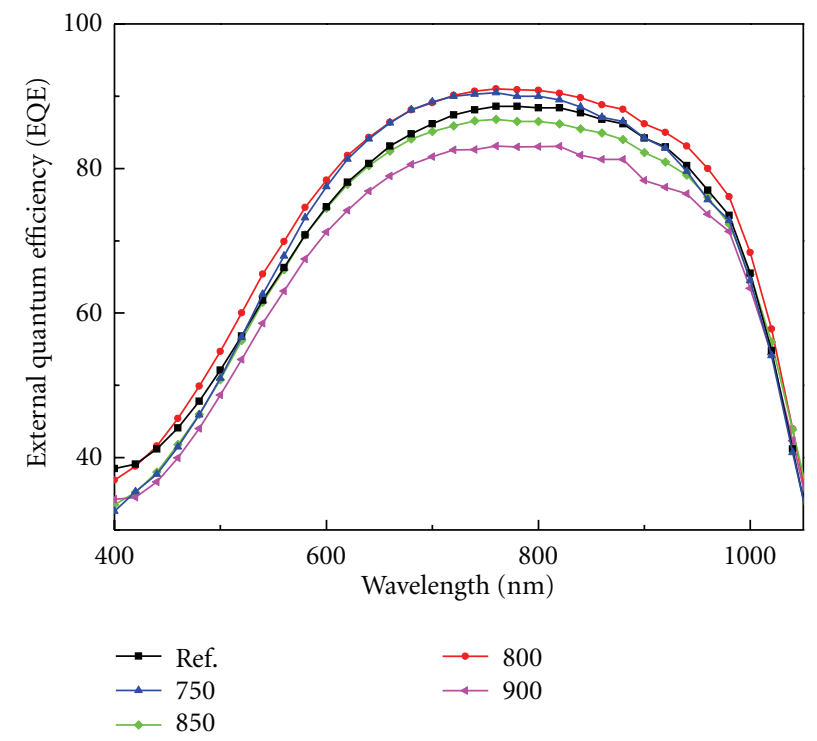

FIGURE 8: External quantum efficiency (EQE) of nongettered and gettered samples.

the optimized $\mathrm{P}$ gettering temperature as a process parameter is to be chosen at $800^{\circ} \mathrm{C}$.

\section{Conclusions}

Extrinsic phosphorus gettering was performed at 750, 800, 850 , and $900^{\circ} \mathrm{C}$ to make high quality of silicon substrates for heterojunction solar cells. $800^{\circ} \mathrm{C}$ gettered sample shows the best characteristics. Their minority bulk lifetimes are 
TABLE 1: Properties of Si heterojunction solar cells.

\begin{tabular}{lcccccc}
\hline $\begin{array}{l}\text { Gettering temperature } \\
\left({ }^{\circ} \mathrm{C}\right)\end{array}$ & Ideality factor & $\begin{array}{c}J_{0}\left(10^{-8} \mathrm{~mA} / \mathrm{cm} 2\right) \\
\text { Quasi-neutral region }\end{array}$ & $\begin{array}{c}V_{\mathrm{oc}} \\
(\mathrm{mV})\end{array}$ & $\begin{array}{c}J_{\mathrm{sc}} \\
\left(\mathrm{mA} / \mathrm{cm}^{2}\right)\end{array}$ & FF $(\%)$ & Efficiency $(\%)$ \\
\hline Nongettered & 1.65 & 1.4 & 577 & 27.8 & 73.9 & 11.9 \\
750 & 1.61 & 1.3 & 583 & 29.6 & 72.2 & 12.5 \\
800 & 1.56 & 0.5 & 598 & 29.8 & 75.3 & 13.4 \\
850 & 1.68 & 1.4 & 581 & 27.1 & 73.7 & 11.6 \\
900 & 1.90 & 7.4 & 572 & 27.1 & 70.3 & 10.9 \\
\hline
\end{tabular}

improved from 368.3 to $660.8 \mu \mathrm{s}$. $V_{\mathrm{OC}}$ and $J_{\mathrm{SC}}$ increase from 577 to $598 \mathrm{mV}$ and from 27.8 to $29.8 \mathrm{~mA} / \mathrm{cm}^{2}$. Saturation current and ideality factors decrease to $0.5 \times 10^{-8} \mathrm{~mA} / \mathrm{cm}^{2}$ and 1.56, respectively. It results in efficiency improvement of silicon heterojunction solar cells. While properties of above $850^{\circ} \mathrm{C}$ gettered samples show degradation, we consider that optimized temperatures exist for extrinsic phosphorus gettering. Through this study, we found the possibility to improve the Si heterojunction solar cells by $\mathrm{P}$ gettering.

\section{Acknowledgments}

This work was supported by a Human Resources Development grant from the Korea Institute of Energy Technology Evaluation and Planning (KETEP) funded by the Ministry of Knowledge Economy, Republic of Korea (no. 20104010100640). This work was also supported by Korea University Grant (no. T1101441).

\section{References}

[1] A. Rohatgi, S. Narasimha, and L. Cai, "Gettering and passivation of high efficiency multicrystalline silicon solar cells," in Proceedings of the American Institute of Physics Conference, vol. 394, pp. 199-213, 1997.

[2] A. Luque and S. Hegedus, "chapter 5. Solar grade silicon feedstock," in Handbook of Photovoltaic Science and Engineering, pp. 188-189, John Wiley \& Sons, 2011.

[3] S. M. Myers, M. Seibt, and W. Schroter, "Mechanisms of transition-metal gettering in silicon," Journal of Applied Physics, vol. 88, no. 7, pp. 3795-3819, 2000.

[4] A. Luque and S. Hegedus, Handbook of Photovoltaic Science and Engineering, John Wiley \& Sons, 2011.

[5] H Nagel, A. G. Aberle, and S. Narayanan, "Method for the evaluation of the influence of gettering and bulk passivation on non-uniform block-cast multicrystalline si solar cells," Solid State Phenomena, vol. 67-68, pp. 503-508, 1999.

[6] A. Bentzen, H. Tathgar, R. Kopecek, R. Sinton, and A. Holt, "Recombination lifetime and trap density variations in multicrystalline silicon wafers through the block," in Proceedings of the 31st IEEE Photovoltaic Specialists, pp. 1074-1077, January 2005.

[7] D. Macdonald, A. Cuevas, A. Kinomura, and Y. Nakano, "Phosphorus gettering in multicrystalline silicon studied by neutron activation analysis," in Proceedings of the 29th IEEE Photovoltaic Specialists Conference, pp. 285-288, May 2002.

[8] A. Cuevas, M. Stocks, S. Armand, M. Stuckings, A. Blakers, and F. Ferrazza, "High minority carrier lifetime in phosphorus-gettered multicrystalline silicon," Applied Physics Letters, vol. 70, no. 8, pp. 1017-1019, 1997.

[9] J. S. Kang and D. K. Schroder, "Gettering in silicon," Journal of Applied Physics, vol. 65, no. 8, pp. 2974-2985, 1989.

[10] L. J. Caballero, C. del Canizo, P. Sanchez-Friera, and A. Luque, "Influence of P gettering thermal step on light-induced degradation in $\mathrm{Cz}$ Si," Solar Energy Materials and Solar Cells, vol. 88, no. 3, pp. 247-256, 2005.

[11] L. Baldi, G. F. Cerofolini, G. Ferla, and G. Frigerio, "Gold solubility in ailicon and gettering by phosphorus," Physica Status Solidi A, vol. 48, no. 2, pp. 523-532, 1978.

[12] S. A. Mchugo, H. Hieslmair, and E. R. Weber, "Gettering metallic impurities in photovoltaic silicon," Applied Physics AMaterials Science and Processing, vol. 64, no. 2, pp. 127-137, 1996.

[13] D. K. Schroder, Semiconductor Material and Device Characterization, John Wiley \& Sons, 3rd edition, 2006. 


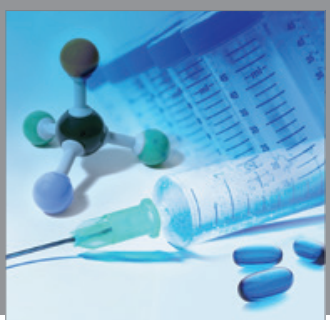

International Journal of

Medicinal Chemistry

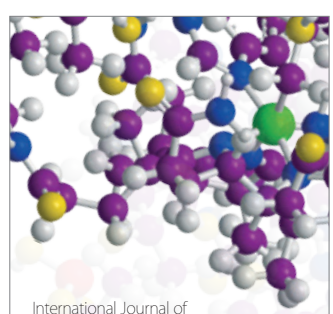

Carbohydrate Chemistry

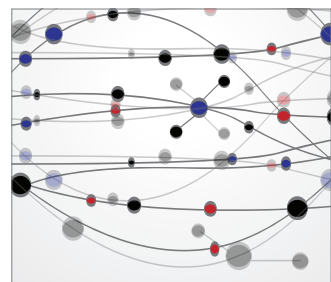

The Scientific World Journal
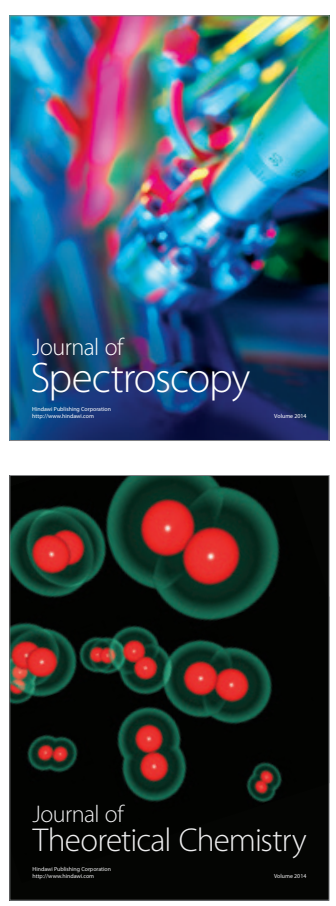
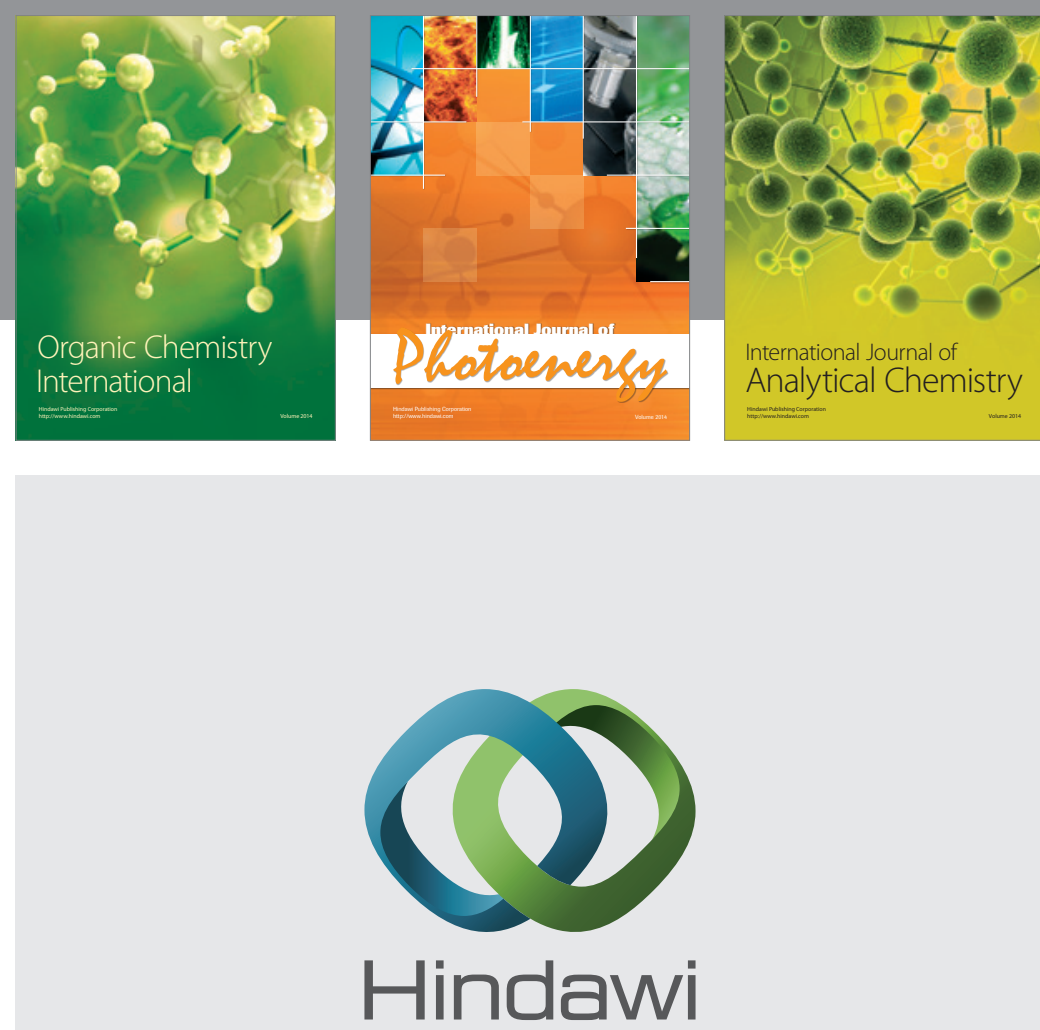

Submit your manuscripts at

http://www.hindawi.com
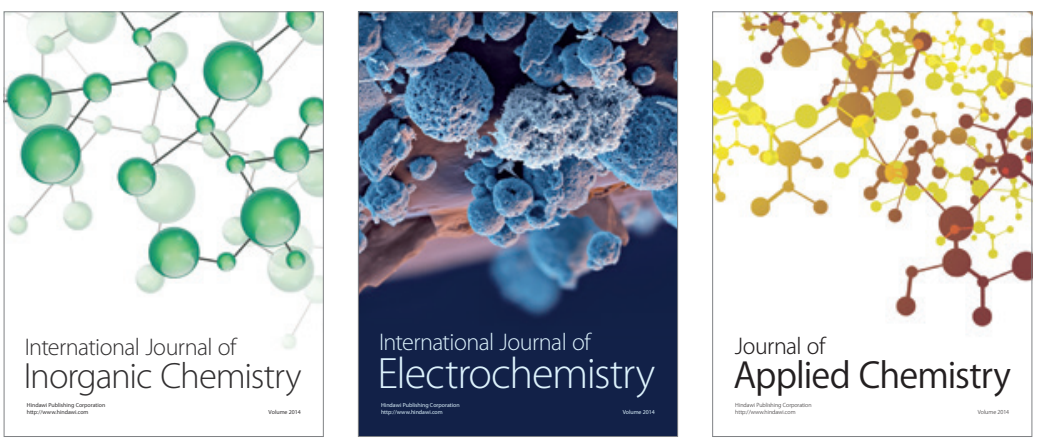

Journal of

Applied Chemistry
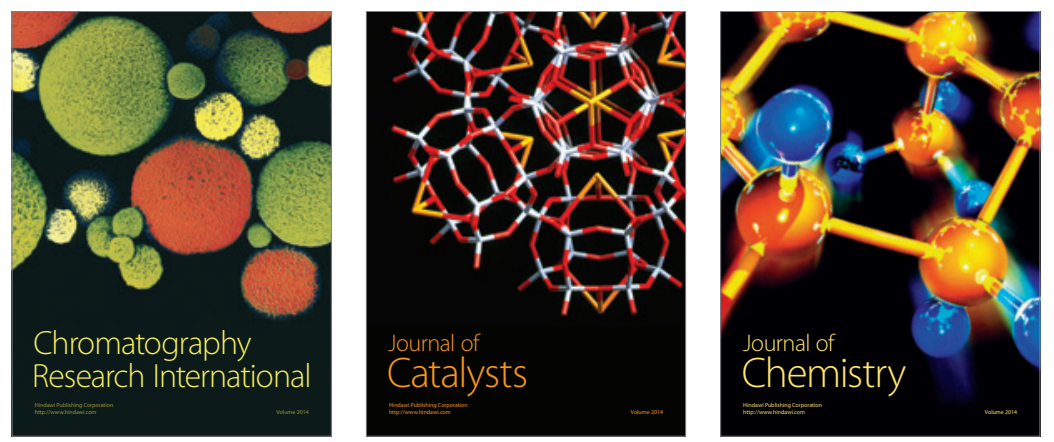
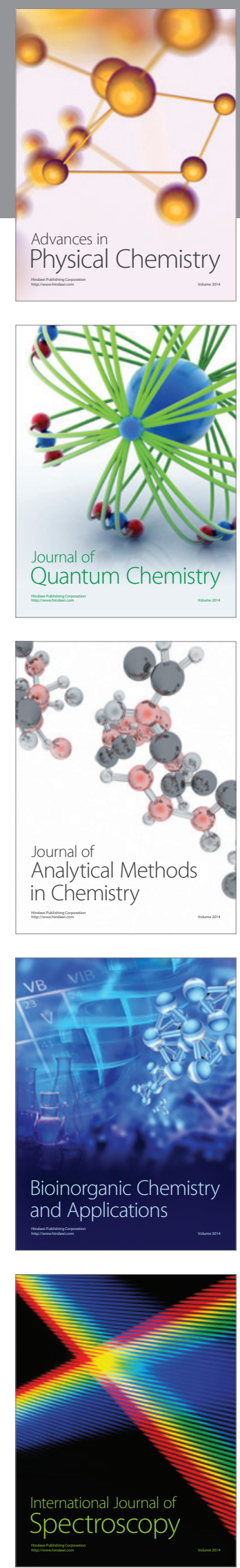